\title{
Effect of desmopressin on normal and impaired memory
}

\author{
JS JENKINS,${ }^{*}$ HM MATHER, ${ }^{*}$ AK COUGHLAN $\dagger$ \\ From *the Department of Medicine, St George's Hospital Medical School, and $\dagger$ the Wolfson Rehabilitation \\ Centre, London, UK
}

SUMMARY In view of the reported influence of vasopressin on the memory process of animals, trials were carried out on normal subjects and patients with memory disorders using the vasopressin analogue desmopressin. No beneficial effects could be demonstrated.

A series of reports by de Wied ${ }^{1}$ over several years have shown that vasopressin can influence the memory process in rats. Following this intriguing finding there have been continuing trials of vasopressin and its analogue desmopressin (DDAVP) in the treatment of patients with various memory disorders. Beneficial effects have been claimed in Korsakoff's syndrome, ${ }^{2}$ affective disorders, ${ }^{3}$ Alzheimer's dementia, ${ }^{4}$ and post-traumatic amnesia. ${ }^{5}$ It has also been reported that vasopressin can improve cognitive function in middle-aged men without obvious brain disorders ${ }^{6}$ and recently it has even been claimed that DDAVP can enhance the memory of young normal subjects. ${ }^{4}$ However, not all these trials have been vigorously controlled, and other investigators have been less successful in obtaining beneficial effects. ${ }^{78}$

Our previously reported negative findings were confined to patients with post-traumatic amnesia but it has been suggested that improvement is most likely to occur in patients with less severe impairment of memory.

Because of the importance of defining the value of vasopressin and its analogues in the treatment of memory disturbances and to determine its effect on the normal memory process we have extended our studies to include less severely affected patients with Alzheimer's type dementia or Korsakoff's syndrome as well as young normal subjects.

Address for reprint requests: Prof JS Jenkins, St George's Hospital Medical School, Cranmer Terrace, London SW17 0RE, UK.

Received 25 March 1982. Accepted 5 May 1982

\section{Patients and methods}

Normal subjects Fourteen students aged 21 to 24 (10 male and 4 female) took part in a double-blind trial. They received an initial assessment of memory which comprised (a) digit span, (b) learning a list of 16 words over five trials, (c) delayed recall of these 16 words, and (d) forced-choice word recognition (presentation of a list of 40 words followed by presentation of 40 pairs of words consisting of a target word and a distractor). Half of the students were then randomly allocated to receive DDAVP intranasally in a dosage of $40 \mu \mathrm{g}$ four times a day for two weeks, and the remaining half received placebo material intranasally for a similar period. At the end of treatment the tests were repeated using a second version of each test. All students were restricted to an intake of one litre of fluid daily.

Patients with memory disorders Three patients with early dementia of the Alzheimer type were studied, comprising a recently retired accountant aged $65 \mathrm{yr}$ who was still working part-time, a navigation instructor aged $58 \mathrm{yr}$, and a housewife aged $64 \mathrm{yr}$. A fourth patient, a male aged $62 \mathrm{yr}$ was investigated who was suffering from more severe memory loss of the Korsakoff type associated with chronic alcohol excess. All four patients were initially given placebo material intranasally and after one week they were subjected to a series of verbal and visual memory tests. These comprised (a) digit span, (b) forced-choice word recognition (50 words), ${ }^{9}$ (c) forced-choice face recognition (50 faces), ${ }^{9}$ (d) the Benton Visual Retention Test, ${ }^{10}$ (e) list learning (learning a 10 word list over five trials), and (f) cued word recall (learning a list of 12 words, two from each of six categories, over five trials with recall prompted by the category name). A double-blind crossover trial was then carried out in which all patients were given either DDAVP $40 \mu \mathrm{g}$ four times daily intranasally or placebo material for one week in random order at intervals of one month and tests were performed at the end of each treat- 
Table Psychometric tests in normal subjects treated with placebo or DDAVP (mean scores $\pm S D$ )

\begin{tabular}{|c|c|c|c|c|}
\hline \multirow[t]{2}{*}{ Test (and max score) } & \multicolumn{2}{|c|}{ Placebo group } & \multicolumn{2}{|c|}{$D D A V P$ group } \\
\hline & Before & After & Before & Afier \\
\hline $\begin{array}{l}\text { Digit span } \\
\text { Word learning }(80) \\
\text { Delayed recall }(16) \\
\text { Forced-choice word recognition }(40)\end{array}$ & $\begin{array}{r}7 \cdot 6 \pm 0 \cdot 5 \\
61 \cdot 1 \pm 6 \cdot 0 \\
13 \cdot 6 \pm 1 \cdot 7 \\
34 \cdot 9 \pm 3 \cdot 1\end{array}$ & $\begin{array}{r}7 \cdot 7 \pm 0.9 \\
58 \cdot 4 \pm 10.4 \\
11 \cdot 1 \pm 3 \cdot 1 \\
36 \cdot 3 \pm 3 \cdot 4\end{array}$ & $\begin{array}{r}7 \cdot 3 \pm 1 \cdot 3 \\
58 \cdot 6 \pm 7 \cdot 1 \\
11 \cdot 0 \pm 2 \cdot 9 \\
35 \cdot 3 \pm 3 \cdot 7\end{array}$ & $\begin{array}{r}7 \cdot 6 \pm 0.9 \\
59.7 \pm 10.3 \\
11.0 \pm 4 \cdot 1 \\
34.4 \pm 4.5\end{array}$ \\
\hline
\end{tabular}

ment period. Three versions of each test were used and the versions rotated amongst the subjects in a restricted Latin square design.

\section{Results}

\section{NORMAL SUBJECTS}

When the group receiving DDAVP was compared with that receiving placebo no significant differences in performance were observed for any of the tests at the $\mathrm{p}<0.5$ level of significance using Students $t$ test (table).

\section{PATIENTS WITH MEMORY DISORDERS}

None of the patients showed significant improvement with DDAVP for any of the test procedures at the $p<0.5$ level of significance.

\section{Discussion}

One of the weaknesses of previous clinical trials of vasopressin and analogues in memory disorders has been a lack of knowledge of their penetration into the central nervous system after systemic or intranasal administration. We now have evidence that, unlike vasopressin, small amounts of unmetabolised DDAVP can pass through the blood-cerebrospinal fiuid barrier ${ }^{11}$ so that it would appear to be an appropriate peptide to choose. Nevertheless, using a similar dosage regimen to that described in a previous favourable report, ${ }^{4}$ we cannot confirm that DDAVP enhances normal memory, nor did it benefit patients with moderate memory deficits due to Alzheimer dementia or Korsakoff's syndrome. We have not studied patients with depressive illness, a group which is said to respond to DDAVP, ${ }^{3}$ but the reported improvement in both mood and memory may indicate a non- specific stimulation of the central nervous system in these cases. The present study, together with previous experiences, lead us to believe that vasopressin and DDAVP are of little practical value in the treatment of those conditions where memory deficiency is the predominant disorder.

We thank Dr B Donovan of Ferring Pharmaceuticals for supplies of desmopressin.

\section{References}

${ }^{1}$ de Wied D. Behavioural actions of neurohypophysial peptides. Proc Roy Soc Lond B 1980;210:183-94.

${ }^{2}$ le Boef A, Lodge J, Eames PG. Vasopressin and memory in Korsakoff's syndrome. Lancet 1978;ii:1370.

${ }^{3}$ Gold PW, Weingartner H, Ballenger JC, Goodwin FK, Post RM. Effects of 1-desamino-8-d-arginine vasopressin on behaviour and cognition in primary affective disorder. Lancet 1979;ii:992-4.

${ }^{4}$ Weingartner H, Gold P, Ballenger JC, et al. Effect of vasopressin on human memory functions. Science 1981;211:601-3.

${ }^{5}$ Oliveros JC, Jandali MK, Timsit-Berthier M, et al. Vasopressin in amnesia. Lancet 1978;i:42.

' Legros JJ, Gilot P, Seron X, et al. Influence of vasopressin on learning and memory. Lancet 1978;i:41-2.

' Jenkins JS, Mather HM, Coughlan AK, Jenkins DG. Desmopressin and desglyanamide vasopressin in post-traumatic amnesia. Lancet $1981 ; \mathbf{i}: 39$.

- Tinklenberg JR, Pfefferbaum A, Berger PA. l-Desamino-D-Arginine vasopressin (DDAVP) in cognitively impaired patients. Psychopharm Bull 1981;17:206-7.

9 Warrington EK. Deficient recognition memory in organic amnesia. Cortex 1974;10:289-91.

${ }^{10}$ Benton AL. Revised visual retention test. New York: Psychological Corporation, 1974.

${ }^{11}$ Ang V, Jenkins JS. Blood-cerebrospinal fluid barrier to arginine vasopressin, desmopressin and desglycinamide vasopressin. J Endocrinol 1982 (in press). 